\title{
KLLN wt Allele
}

National Cancer Institute

\section{Source}

National Cancer Institute. KLLN wt Allele. NCI Thesaurus. Code C95287.

Human KILLIN wild-type allele is located in the vicinity of $10 \mathrm{q} 23$ and is approximately $4 \mathrm{~kb}$ in length. This allele, which encodes killin protein, plays a role in both DNA binding and the mediation of p53-mediated apoptosis. 